\title{
ARTICLES \\ ARTICULOS \\ NARRATIVES OF SUFFERING IN THE PRESS: the construction of scenes and the place of the subject
}

Copyright $\odot 2015$ SBPjor / Associação Brasileira de Pesquisadores em Jornalismo

\author{
DANILA CAL \\ Universidade Federal de Minas Gerais and Universidade da \\ Amazônia, Brazil \\ LEANDRO LAGE \\ Universidade Federal de Minas Gerais and Universidade da \\ Amazônia, Brazil
}

\begin{abstract}
The article seeks to understand the narrative strategies mobilized by press journalism to expose scenes of suffering related to child domestic labor, considered by social organizations as one of the activities in which children and adolescents are more oppressed and have their rights violated. It starts with the theoretical discussion of "politics of pity" (H. Arendt) in order to understand in journalistic narratives the suffering appropriations considering the narrative configuration of scenes and of the suffering subjects. It explores ethical issues underlying these reports, questioning narrative strategies which are commonly recommended to reporters, as the thematization of injustices in the form of the complaint and a description of characters and life stories in the narratives. It concludes, in the light of the language of pity, that these stories are decisive for how child domestic labor is configured or not as a public issue and to understand the gestures of portrayal the suffering in the journalistic narratives.
\end{abstract}

Keywords: Narrative. Press journalism. Suffering. Child domestic labor. Pity.

\section{NARRATIVAS DE SOFRIMENTO NO JORNALISMO IMPRESSO: a construção de cenas e o lugar dos sujeitos}

RESUMO - O artigo busca compreender estratégias narrativas mobilizadas pelo jornalismo impresso para constituir cenas de sofrimento ligadas ao trabalho infantil doméstico, considerado uma atividade laboral opressora e cerceadora dos direitos infanto-juvenis. Parte-se da discussão teórica sobre a "linguagem da piedade" (H. Arendt) para entender, a partir do exame de matérias jornalísticas sobre o tema, os modos de narrar o sofrimento e a inscrição narrativa dos sujeitos sofredores. Exploram-se questões éticas subjacentes a esses relatos, problematizando-se estratégias narrativas comumente recomendadas aos jornalistas, como a tematização de injustiças sob a forma da denúncia e a inscrição de personagens e histórias de vida. Conclui-se, à luz da linguagem da piedade, que essas histórias são decisivas para o modo como o trabalho infantil doméstico se configura ou não como problema público e para a compreensão dos gestos de retratação do sofrimento nas narrativas jornalísticas.

Palavras-chave: Narrativas. Jornalismo impresso. Sofrimento. Trabalho infantil doméstico. Piedade. 


\section{NARRATIVAS DE SUFRIMIENTO EN EL PERIODISMO IMPRESO: la constitución de escenas y el lugar de los sujetos}

RESUMEN - El artículo pretende comprenden estrategias narrativas movilizadas por el periodismo impreso para constituir escenas de sufrimiento conectadas con el trabajo infantil doméstico, considerado una actividad laboral opresora y cercenadora de los derechos infanto-juveniles. Se parte de la discusión teórica sobre la "lengua de la piedad" (H. Arendt) para entender, a partir del examen de materias periodísticas sobre el tema, los modos de narrar el sufrimiento y la inscripción narrativa de los sujetos sufridores. Se exploran cuestiones éticas subyacentes a esos relatos, problematizándose estrategias narrativas comúnmente recomendadas a los periodistas, como la tematización de injusticias bajo la forma de la denuncia y la inscripción de personajes e historias de vida. Se concluye, a la luz del lenguaje de la piedad, que esas historias son decisivas para el modo como el trabajo infantil doméstico se configura o no como problema público y para la comprensión de los gestos de retractación del sufrimiento en las narrativas periodísticas.

Palabras clave: Narrativas. Periodismo impreso. Sufrimiento. Trabajo infantil doméstico. Piedad.

\section{INTRODUCTION}

Modern life offers us many opportunities to see the pain of others (SONTAG, 2003). Either through photographs or by television images, journalistic media set up daily our encounter with victims of injustice and with all sorts of unfortunates. Faced with such an evident problem, numerous studies have been devoted to the understanding of journalistic narratives (SODRÉ, 2009; MOTTA, 2004; 2013; LEAL; CARVALHO, 2013), in particular those that report experiences of suffering arising from situations of exploitation and violence, disasters and wars (RESENDE, 2009; VAZ; RONY, 2011 ; TAIT, 2011 ; ANTUNES, 2012; LAGE, 2013; 2015).

Research into journalistic narratives of suffering, however, tend to focus on photojournalism (ZELIZER, 2007; PICADO, 2009; BIONDI; VAZ, 2011) and journalistic approaches (CHARAUDEAU, 2006; CHOULIARAKI, 2006a, 2006b; 2009; FROSH, 2009; SERELLE, 2012), thanks to the images that build a specific iconography of suffering woven daily by the journalistic media. Furthermore, many other forms of narratives, from the daily press to the literary one, not to mention the online journalism and collaborative and transmedia journalistic activities, are rarely discussed. The same occurs with certain themes in which the suffering shown is less evident- those 
which, for example, escape the logic of events that produce numerous victims.

In an attempt to broaden the discussion so as to include other forms of narrative journalism, as well as less prominent themes (that are, for this reason, also relevant), we will examine the narrative strategies used by print journalism to build and portray scenes of suffering associated with the lives of working children and adolescents. We therefore intend to focus on narratives that, in a sense, provide insight on the ways daily journalism appropriates experiences of suffering - in our specific case, the misfortune of girls' domestic labor. We propose, in short, to review these journalistic appropriations of suffering, in the written press reports in the state of Pará, where the problem is, at the same time, serious and little evident, in search of clues that lead us to understand how a very peculiar way of portraying those domestic child workers and former workers is implied. In order to do that, two aspects will be taken into consideration: the narrative configuration of scenes of suffering; and the portrayal of the sufferers in the accounts of these experiences.

It is important to emphasize that such effort arises from the conjunction of two studies: one, with the political configuration and power relations in domestic child labor (CAL, 2014); and the other, with the narratives and media testimonies of suffering (LAGE, 2013; 2015). During the research on domestic child labor, some narrative schemes that organized such stories of suffering were recurrent, reserving, for those child workers, not only a place of subordination, but the status of victims that, as a rule, are unable to recognize their own state of suffering.

\section{EMPTY PROMISES AND THE UNSEEN SUFFERING}

On the edition of March 30, 2008, the newspaper Diário do Pará told the story of Maria Aparecida dos Santos, in a news story entitled "Work still threatens childhood", subtitled "A lifetime of sacrifice since the age of 5 ". CIDA, the character of that narrative, was born in 1964, in Vigia, a city of Northeastern Pará. At five years old, she moved to the capital where she lived with her godmother. "The promise was to educate her and promote education and employment opportunities. She never saw her illiterate parents or siblings again. She spent her childhood carrying groceries, washing floors, cooking 
and ironing clothes" (ZAGHETTO, 2008, p. A10). In this account, Cida's drama is evoked to reveal what it means, "in practice", to work during childhood, which is the central theme of that news story.

Stories like those of Cida are quite common in the Amazon region, particularly in Pará. As several authors pointed out (CAL, 2014; LAMARÃO, 2008; MOTTA-MAUÉS, 2012), it is common for girls from the countryside in the State of Pará to leave their houses to work in family homes in the capital, where domestic child labor, although increasingly discussed in the media, is an historically established practice. Cida's drama, at the same time individual and collective, brings into play domestic child labor itself as a matter of politics, creating approaches on gender issues and on the exploitation of children and adolescents. This drama shows, too, an apparently conventional way of telling these stories of suffering.

The fate of Cida, in the narrative of the newspaper Diário do Pará is the same as most domestic child workers (LAMARÃO, 2008; CAL, 2014). During the colonial period, slave women and girls worked in the houses of their masters, taking care of their children, performing all kinds of domestic service and, not infrequently, suffering sexual abuse on the part of their masters (LAMARÃO, 2008). The core of this practice still endures in Pará, where girls are taken from the countryside to work in family homes in the capital in exchange for food, clothing and schooling. These girls are treated as "offspring" (raised as a member of the family) or "goddaughters", as in the case of Cida, and their relationship with their employers is marked by ambiguity of being sometimes part of the family and sometimes housekeepers or nannies, which is rarely questioned by the working girls, although it causes suffering and frustration (LAMARÃO, 2008).

In general, domestic working girls lose contact with their families of origin and are unsuccessful in their studies, due to their long working days and the lack of appropriate time and space to study during their daily routine of domestic work. Therefore, there is an increasing dependence on the employers who allegedly raise them as part of the family, "since nothing they want and desire belongs to them, but to the family, that, as a constant threat, can give or take according to the circumstances" (CARNEIRO; ROCHA, 2009, p. 134135). For these reasons, child labor is considered one of the most oppressive labor activities: "children, in their subordinate position to adults, are even more exposed to situations of exploitation and 
abuse as domestic workers" (ARAGON-LAGERGREN, 2003, p. 100). According to the International Labour Organisation (ILO, 2011), child domestic workers are more likely to be exploited and are the hardest to be protected.

After examining the coverage of domestic child labor over ten years (2000-2009) in two local newspapers, O Liberal and Diário do Pará, we identified that the first news about domestic child labor were encouraged by surveys carried out by the ILO, the United Nations Children's Fund (Unicef) and by the Centre for the Defense of Children and Adolescents (Cedeca-Emaús) (CAL, 2014). In the narratives analyzed, it was up to the workers and former-workers to narrate situations they experienced while working as maids, to give details of their daily routine, to speak of the relationship with the employing family and to tell the sufferings to which they were subjected. What girls and women affected by domestic child labor could express was mainly confined to the sufferings they experienced in their daily toil, restricted to the homes where they worked.

The journalistic narratives we analyzed regarding domestic child labor bring together at least two recurring features, which, in our view, are traces of a "language of pity". The first concerns suffering as an element of a specific social context, an evidence of a political issue arising from the exposure of the misfortune of others; the second relates to the appearance of the subjects as exemplary, as individuals whose stories are, indeed, the stories of others, whose sufferings are similar to that of others.

Before looking at how these aspects are developed in some of those narratives, we still need to explore conceptually the problems related to how suffering is narrated as well as the issues governing the emergence of these suffering subjects in these narratives.

\section{THE EXPLOITATION OF SUFFERING AND THE EXEMPLARY SUFFERER}

In modernity, suffering has become an issue which is very frequently addressed by the media, in particular by journalistic narratives to denounce injustice and trigger political actions. The exploration of a rhetoric of suffering began at least two hundred years, when, according to Boltanski (1993), supported by $\mathrm{H}$. Arendt, the French Revolution created the conditions for the emergence of a 
political language of pity anchored in a feeling of solidarity provoked by the "spectacle of suffering "of other people. For Arendt (2011), at that time, a form of politics was established anchored in the use of a rhetoric of pity focused on resolving the "social question", which, in turn, made the suffering of others a moral issue on which we must act.

In the rhetoric of pity, therefore, the suffering is associated with certain social conditions that defy the political cause saying that any sufferer deserves help. And anyone who faces the suffering of others must help. Yet, there is an important difference between pity, compassion and solidarity, with great impact in the ways of narrating the suffering of others. While compassion has an individual and intersubjective component and solidarity has a general character, pity is related to an attraction for human misery and misfortune. According to Arendt:

\begin{abstract}
pity, in contrast to solidarity, does not look upon both fortune and misfortune, the strong and the weak, with an equal eye; without the presence of misfortune, pity could not exist, and it therefore has just as much vested interest in the existence of the unhappy as thirst for power has a vested interest in the existence of the weak (ARENDT, 1965, p. 89).
\end{abstract}

Pity, in this sense, can be understood as the perversion of compassion. And, unlike solidarity, it is interested only in the misfortune and weakness of others, without which it could not exist. The narratives of the politics of pity, according to Arendt's perspective, are interested in suffering by suffering, as an excuse to support a cause. On the other hand, it cannot be said that they return to the sufferer only by exposing the suffering: they are ways of narrating that transform the sufferer into a member of a community or a group of sufferers. Subjects are stripped of their individuality, their uniqueness, in favor of the suffering which makes them part of a group of unfortunates.

The role of the other, in these reports, is to join a community of sufferers who need the aid of the blessed ones. In this context, in which language revolves around pity for victims of poor social conditions that generate misfortune, the suffering of others is necessarily seen from a sentimental and even physical distance. This topos is, thus, the language of pity, whose characteristics are, primarily, the exploitation of suffering per se and the exemplarity of the sufferers.

Despite the current persistence of various aspects highlighted 
in the theoretical investment on the rhetoric of pity by $\mathrm{H}$. Arendt and her readers (BOLTANSKI, 1993), it is necessary to understand and consider the differences between the social and political reality of the 18 th and $21 \mathrm{st}$ century, regarding the narrative constructions about suffering (VAZ; RONY, 2011).. This is especially true when dealing with specific narrative modes, such as journalistic reports. On the other hand, we must also consider the permanence in time of certain "ways to tell". This stability helps to establish such narrative modes. As Motta reminds us,

Journalism is a mimetic activity: it represents life, the actions of men, either good or bad, reports the dramas, tragedies, sagas and epics of our times. The news consists in fragmented and contradictory reports about our existence, our pain and our love, our sufferings and rewards, about the chances and contingencies that affect us (MOTTA, 2004, p. 15, our translation).

If journalism, as a narrative activity, is geared especially towards a social adventure, it is certain that the ways and strategies of narration change with time, according to social transformations. The journalistic media, when narrating experiences of suffering, increasingly direct our compassion towards real individuals, by talking about their past (VAZ; RONY, 2011). The insertion of real individuals, with their personal stories, transforms the general and impersonal outcry of mercy in a demand for compassion. In this sense, the rhetoric of pity gives place to a new rhetoric, that of the production of the "virtual victim", carefully identified and singularized.

We believe, however, that evoking the approach Arendt used when dealing with the rhetorical forms of a peculiar political context of the past to treat the current media context does not necessarily imply the abandonment of those categories. These, in a sense, are still useful to understand certain journalistic appropriations of suffering in contemporaneity. As stated by Chouliaraki (2006a, p. 265), "the politics of pity still performs the crucial political function of presenting human misfortune in public with a view to arousing the emotion of the spectators as well as inviting their impartial deliberation on how-to-act upon the misfortune".

In what remains of the politics of pity, the persistence of journalistic narratives of suffering and the constitution of scenes in which subjects such as domestic child workers are portrayed 
are of importance to us. Our aim is, therefore, to broaden the vision which tends to favor a certain category of mostly visual journalistic narratives to include narratives of daily print journalism-favoring, for the sake of scope, verbal informationas well as experiences of suffering related to child labor. In pursuing this goal, we will seek to observe narratives, such as those concerning Cida, in the light of the assumptions which form the basis of the concept of the language of pity, in order to understand how journalism appropriates the suffering of others in contemporaneity, as well as to observe the ways in which such appropriation gives rise to the constitution of this suffering as a political problem-that is, how journalism constructs domestic child labor as a matter we must act on.

\section{METHODOLOGICAL NOTES}

Before discussing examples of journalistic narratives of suffering in the context of domestic child labor, it is necessary to make some considerations about the operations of narratives that allow the construction of scenes of suffering, as well as on the positions occupied by the sufferers in those scenes, standard categories of our analysis.

For Chouliaraki (2006b), journalism builds the misfortune of others from the narrativization of scenes of suffering. Although the author is interested in the analysis of TV news narratives, the setting of these scenes occurs "concealing and acknowledging the meaning affordance of each medium (Chouliaraki, 2006b, p. 38). That is, the construction of scenes of suffering does not deal only with television reports, but also with the media narrative activity itself in portraying the pain of subjects through the thread of plots and the description of these contexts of suffering.

This perspective supports the perceptions of Frosh (2009) about the capacity that written testimonies have to activate the imaginary presence of the readers in the reported scenes. The relevance of the scenes of suffering, in this sense, lies in their potential to contextualize and detail the situations and conditions of suffering to which a person is subjected. Thus, they constitute an essential dimension of the journalistic mediation, through narrative, between the reality of those who suffer and 
those who become aware of the misfortune of others. These scenes become, consequently, more than a category of narrative analysis; they become also an ethical category that defines the place of suffering.

According to Tait (2011), in the analysis of certain narratives of suffering, interest is placed as much on the wealth of detail described in the contexts and situations of pain, as on the places occupied by victims of suffering in the course of these accounts, as well as on the narrator in relation to sufferers. After analyzing the journalistic coverage of the Darfur conflict, by Nicholas Kristof, who was awarded the Pulitzer Prize for journalism, the author realized that, in that set of journalistic reports, the narrator not only puts himself in the scenes of atrocities, but also in the place of those who claim for effective action oriented towards the reality which is narrated.

In this sense, as in the scenes of suffering, the place of the subjects appears as an ethical and narrative category, and can be understood from the discourse reproduced within the journalistic narratives, as well as from the narrative entanglement of the characters, from their ambitions and wills in predetermined social places, such as that of subordination, the excessive poverty, or even ignorance and lack of education. Therefore, we take the places of the subjects not only from the point of view of their inscription in the scenes of suffering, but also from their role in the course of the stories told about themselves and about their lives.

From the set of journalistic narratives observed, we have selected two episodes to be examined: the trajectory of Cida, presented at the beginning of the article, and the one that addresses the life context of a teenage girl, "Miss L. S", as a child domestic worker. We believe that these texts are representative of the way the life stories of child domestic workers are portrayed in the news about the topic.

\section{5 “AN ENTIRE LIFE OF SACRIFICE"}

From the outset, the narrative about Cida's life points out the importance given to the testimonies of child domestic workers: "If the statistics are excellent indicators of the social injustices, the stories and 
human dramas reflect what the numbers indicate. The story of Maria Aparecida dos Santos reveals, in practice, what it is to work during childhood" (ZAGHETTO, 2008, p. A10b). Considering the impersonality of the statistics on domestic child labour, the journalistic narrative about Cida's life promises to explore the tragedies and sufferings experienced first-hand by child domestic workers. Despite the focus on these subjects' life stories, on their own dramas and experiences, the Diário do Pará narrative also builds a desingularization: Cida's life is mainly presented as an example of the story of women who were themselves, "in practice", child domestic workers.

Throughout the journalistic text, the scenes of suffering and exploitation undergone by Cida are constructed in detail: "she spent her childhood carrying groceries, washing floors, cooking and ironing clothes" (ZAGHETTO, 2008, p. A10). These processes of contextualization are corroborated by the words of the character, whose place in the narrative is strictly limited to the role of a sufferer, a victim who does not realize the exploitation process to which she is subjected:

\footnotetext{
I sang lullabies to each one of the children born in the family, reports Cida. To study? She tried, but was too tired because of so many activities. 'I think my head wasn't made for studying ', she humbly says. I never had new clothes, a suitable place to study, nor the incentive to fulfil my dreams (ZAGHETTO, 2008, p. A10, our translation).
}

The suffering experienced by Cida is spelled out as her testimonies are included in the narrative whose main strategy consists in interpreting them as reports of a wasted life spent working. The story, more than exploiting the suffering of others as a mere misfortune, tries to recognize, in the character's body, gestures and speech, the incarnation of suffering. Cida's appearance is also depicted as an expression of suffering. "It reveals a life of sacrifice: calloused hands, an aged appearance, a tired look " (ZAGHETTO, 2008, p. A10, our translation).

Cida says, without regret, that she took care of all the children in the employing family and she seems resigned about her failure at school. It is the journalist herself who reveals the suffering by introducing and analyzing Cida's words, it is also the journalist who mentions fatigue as one of the justifications for Cida's failure at school. She also depicts another feature of the character's suffering, when highlighting that Cida always wore hand-me-down clothes, never had a space she could call her own, nor "any incentive to fulfil her dreams". The weaving of the 
narrative creates certain complicity between the reader and the journalist who, beforehand, become aware of Cida's suffering while she points out aspects she considered positive in her relationship with the employing family.

The tale of Cida's misfortune is reinforced by the ironic reference to the illusion of an apparent absence of oppression: "'I was treated as one of the family. The godfather only ate the cakes I made', she says proudly. The reason she did not have a day off, and even less vacation, was perhaps because she was part of the family. She never married" (ZAGHETTO, 2008, p. A10, our translation). The irony present in this excerpt clearly marks the distance between the interpretation of the character herself when she reports her experiences and the mastery of words by a narrator who clearly assumes a posture of knowing - and not only of knowing but of knowing more than the other about the other and their own condition, reserving them a place of subordination, naivety and ignorance.

Confronted with the life story of Cida and in an attempt to break the illusion of non-domination, the reporter engages actively in the narrative, and gives details on the moment she intervened: "I explained to Aparecida what child labor was. A long silence stood between us (...) " (ZAGHETTO, 2008, p. A10, our translation). The woman who had embodied marks of domestic service from the age of five had therefore needed an external agent - the very journalist in charge of the report - to realize what had happened to her, to know what "domestic child labour" was.

The journalist, this supposedly discrete narrator, who camouflages and tries to delete oneself as mediation, ends up taking a central place in the story when suggesting that the conscience of that former child domestic woman should be "brought to light". We understand that the gesture of the narrator, in this case coherent with the position of ignorance and subordination with which the narrative inscribes the character, shows the construction of scenes of suffering and unveils the places occupied by the subjects as categories that are not only narratives but also ethics- since they reveal the political relations that arise in the weaving of journalistic intrigue.

By revealing to Cida that the situation in which she lived was analogous to slavery, the journalist is configured as a subject who inflicts the suffering. The scene of suffering caused by the reporter's intervention becomes even more evident in the description of the long 
silence that follows between Cida and her, "(...) until she smiles and let go of the grief she had concealed during her the whole life: ' in my time, the government did not care if they took us away from our homes to serve as a child-slave '. I ask her what she would do if she could change the past: ' Oh, I would have been a teacher ... or a nurse. I think it's beautiful ", she says, smiling "(ZAGHETTO, 2008, p. A10, our translation).

The last question from the reporter returns to the narrative of suffering but in a different manner, not by what Cida had lived and suffered, but by pointing out again the misfortune of the unlived life, the life projects that were frustrated by domestic child labour. She returns to what, from the beginning of the narrative, really mattered: the character's suffering, one among many other domestic child workers. At the core of the interest in Cida's tale, there is an even greater concern for her suffering, which becomes the source of both the authenticity and entanglement of an exemplary character, as alleged virtues of that report.

\section{THE EVERYDAY LIFE OF THE GIRL L.S: "VIOLATED RIGHTS"}

Published in the $O$ Liberal newspaper on March 15, 2002, the story of L.S. is presented under the heading "Teenager has rights violated", linked to the report "Survey describes domestic child labor". The lead story deals with preliminary data from a survey conducted by Cedeca-Emaús on this kind of child labor in Belém. The daily routine of the girl L.S. - as she is identified in the journalistic text is built to demonstrate the tragedies and the tensions present in the lives of adolescent maids:

\footnotetext{
The 14-year-old girl L. S. is a typical example of a child maid who has a series of rights violated. ... She dropped school at grade fifth of elementary school, she gets $R \$ 150$ a month, keeps $R \$ 100$ and sends the rest to her mother who lives in the municipality of Moju, in one of the two days off she has a month (RESEARCH..., 2002, p. 05, our translation).
}

The construction of the scene begins with the account of the life of the teenager, who stopped studying, earns less than a minimum wage, which at the time was $R \$ 200$, and still uses it to help her mother, a resident of Moju, $155 \mathrm{~km}$ from Belém, when she visits her on one of the two monthly days off given by her employers. When presenting L.S. as a "textbook example" of child 
maid, the journalistic narrative soon gives away the exemplarity of that character. In doing so, it makes L.S. part of that unfortunate working group, a kind of sample to corroborate the criticism of domestic child labor.

The journalistic discourse of suffering is reinforced by the girl's account about the restrictions imposed by the employer:

\begin{abstract}
"It's been a long time since I talked to my parents, because she (her employer) won't let me make phone calls, only if something happens to the baby". She says that when her employer asked her aunt, who lives in Belém, to bring her, she said it was just to take care of a baby. When she arrived at the home she realized that she would do the other household chores. "I do everything except for the laundry, because they all work and get home at night" (RESEARCH ..., 2002, p. 05, our translation).
\end{abstract}

The pain, in this case, is not caused by corporal punishment, but by overwork and the curtailment of the rights of the adolescent, like studying and keeping in touch with the family: "L.S. said that she's not studying because her employer 'doesn't want a girl that takes time off to study because of the baby"'. The discourse is part of the context of suffering as the teenager's wishes and rights are relegated to the background due to her duties as a nanny. A scenario is shaped little by little in which the restrictions become obvious, as the teenager is expected to be always available to fulfill her role, even if it results in serious harm to her.

The way the story of the teenager is told by the journalistic narrative focuses on the violations and deprivation of rights related to domestic child labor. The adolescent appears, in that narrative, as an object "handed over" by the aunt, being placed as a passive victim against the employer's restrictive constraints and demands. So, L.S. finds herself in the position of fellow- sufferer, narrated in a rather peculiar mode: a character that does not react to the situation of exploitation in which she is inserted. The reality of domestic child labor, based on this "typical example", is described, above all, as a concealing condition, that is, as a scene in which subjects suffer because they are exploited and cheated by those who promise to protect them.

The construction of the narrative highlights the journalistic aim of detailing the suffering, which is typical of the language of pity, in an attempt to find new elements to construct the scene of suffering in which the girl L.S. is inserted: "When asked if she suffered 
ill-treatment, she said no, but in the middle of the conversation she ends up telling about the 'scolding'. 'I don't like to get yelled at, not even my father does that', she resents" (RESEARCH..., 2002, p. 05, our translation). The revealing of the issue of ill-treatment occurs almost as if the girl's recounting that she had not suffered physical violence was an unexpected outcome in an "exemplary" situation of domestic child labor.

\section{FINAL CONSIDERATIONS}

At first glance, journalistic narratives about controversial topics, which denounce injustices and, to this end, make use of real characters whose stories help to highlight political issues, may seem appropriate gestures to the deontological rules that endorse journalistic practices. However, the description of the scenes of suffering and the predetermined roles of Cida and the girl L.S. as suffering subjects in those narratives are important indicators of what we are doing under the rubric of the "language of pity". In addition to the display of the suffering of those women and the example they provide for the narrative logic of using one case as the rule, those narratives reinforced the subordination of those subjects seen as victims of an oppressive condition against which there are no forms of resistance, nor possible solutions.

The examples examined reveal the problematic nature of certain journalistic narratives from an ethical point of view. If, at first, those stories may seem to be sensitive efforts toward certain themes as well as subjects going through an ordeal, an analysis concerned with the way of narrating the suffering and how the sufferers are inserted into these narratives can reveal nuances and new perspectives to certain journalistic strategies and approaches.

In general, the study of certain themes in the form of complaints and the insertion of characters, their life stories and testimonies are usually recommended procedures for certain journalistic guidelines. In this sense, the analysis undertaken proved to be a valid effort of trying to understand the ways in which the pain makes itself visible through the journalistic narratives, with all the ethical issues underlying the insertion 
of the subjects, the description of the scenes and contexts of suffering and the posture of the narrators when faced with experiences of suffering.

According to Vaz and Rony (2011), what could be a transformation or even the overcoming of the language of pity for the virtual victim's rhetoric, actually implies the continuity of that example, though disguised as the exploitation of the specific case. The strategy employed by those journalistic narratives uses a specific example to tell a story and, conversely uses the story to reinforce the example of the suffering not only of Cida or L.S., but of many workers and former domestic child workers.

The basis of the so-called language of pity seems to provide important clues for understanding certain journalistic narratives of suffering. As Arendt (2011) warned, pity mingles easily with compassion when one notices the presence of a zèle compatissant that, nonetheless, does not motivate the disposition to act in the face of suffering, but feeds on its own suffering when faced with it, as there seems to be no possible action.

On the other hand, as Scannell (2009) reminds us, it is common to complain that the media "parasitize" certain events, taking advantage of what they can provide in terms of images and reports. The narratives about children workers who have had a lifetime of hard work, confined in somebody else's homes, subject to various forms of violence, could easily be the target of such criticism. However, it is still important to consider the relevance of these journalistic narratives about human "dramas and tragedies" (MOTTA, 2004), in order to reaffirm the political relevance not only of the situations of suffering denounced, but of the life of certain subjects.

The persistence of this dilemma reaffirms the need to understand the journalistic narratives that build scenes of suffering and the subjects who suffer. In light of the language of pity, these stories bring decisive repercussions for the configuration (or not) of domestic child labor as a political problem that concerns everyone, as well as for the journalistic narratives in their gestures of renunciation of the suffering of others.

*This paper was translated by Viamundi 


\section{REFERENCES}

ANTUNES, E. Acontecimentos violentos, ressentimento e as marcas de uma interpretação. In: FRANCA, V. R. V.; OLIVEIRA, L. (Org.). Acontecimento: reverberações. Belo Horizonte: Autêntica, 2012, p. 269-292.

ARAGÃO-LAGERGREN, A. Urban informal sector. The case of Child Domestic Work in Guatemala City. Revista da Faculdade de Letras Geografia, Porto, v. XIX, n. 1, p. 99-109, 2003.

ARENDT, H. On revolution. Londres: Penguin Books. 1965.

LAGE, L. Witnessing on TV: Profissão Repórter and the staging of staging. Intercom, v. 38, p. 139-156, 2015.

LAGE, L. O testemunho do sofrimento como problema para as narrativas jornalísticas. Contracampo, v. 27, p. 71-88, 2013.

BIONDI, A.; VAZ, P. B. Figuras solenes, fatos qualificados. Narrativas de vida e morte no fotojornalismo. Eco-Pós, v. 14, n. 2, p. 97-109, 2011.

BOLTANSKI, L. La souffrance à distance: morale humanitaire, médias et politique. Paris: Métailié, 1993.

$C A L, D$. Configuração política e relações de poder no trabalho infantil doméstico: tensões nos discursos dos media e de trabalhadoras. 298f. Tese (Doutorado). Universidade Federal de Minas Gerais, Programa de Pós-Graduação em Comunicação Social, Belo Horizonte, 2014.

CARNEIRO, M.T.; ROCHA, E. Do fundo do buraco: o drama social das empregadas domésticas. In: SOUZA, J. A ralé brasileira: quem é e como vive? Belo Horizonte: UFMG, 2009, p. 125-142.

CHARAUDEAU, Patrick. A televisão e o 11 de setembro: alguns efeitos do imaginário. Logos, v. 13, n. 1, p. 11-20, 2006.

CHOULIARAKI, L. The aestheticization of suffering on television. Visual Communication, v. 5, p. 261-285, 2006a.

CHOULIARAKI, L. The spectatorship of suffering. London: Sage, 2006b.

CHOULIARAKI, L. O 11 de setembro, a sua colocação em imagens e o sofrimento à distância. In: DAYAN, D. O terror do espectáculo: terrorismo e televisão. Lisboa: Edições 70, 2009, p. 173-192.

FROSH, P. Telling presences: witnessing, mass media, and the imagined 
lives of strangers. In: FROSH, P; PINCHEVSKI, A. (Org.). Media witnessing: testimony in the age of mass communication. Basingstoke: Palgrave Macmillan, 2009, p. 49-72.

LAMARÃO, M. L. A constituição das relações sociais de poder no trabalho infanto-juvenil doméstico: estudo sobre estigma e subalternidade. 2008. Dissertação (Mestrado em Serviço Social) - Universidade Federal do Pará, Belém, 2008.

LEAL, B. S.; CARVALHO, C. A. (Org.). Narrativas e poéticas midiáticas: estudos e perspectivas. São Paulo: Intermeios, 2013.

MOTTA, L. G. Jornalismo e configuração narrativa da história do presente. E-Compós, n. 1, v. 1, p. 1-26, 2004.

MOTTA, L. G. Análise Crítica da Narrativa. Brasília: UnB, 2013.

MOTTA-MAUÉS, M. Uma mãe leva a outra (?): práticas informais (mais nem tanto) de "circulação de crianças" na Amazônia. Scripta Nova, Barcelona, v. XVI, n. 398, p. 1-24, 2012.

OIT. Notas OIT: O Trabalho Doméstico Remunerado na América Latina e Caribe. OIT, 2011 , p. 1 - 4.

PESQUISA traça o painel do trabalho infantil. O Liberal, Belém, 15 mar. 2002.

PICADO, B. A ação e a paixão que se colhem num rosto: pensando os regimes de discurso do retrato humano no fotojornalismo. Galáxia, v. 18, n. 2, p. 284-299, 2009.

RESENDE, F. A. O jornalismo e suas narrativas: as brechas do discurso e suas possibilidades de encontro. Galáxia, São Paulo, v. 18, p. 31-43, 2009.

SCANNELL, P. Qual é a realidade da desgraça? In: DAYAN, D. O terror do espectáculo: terrorismo e televisão. Lisboa: Edições 70, 2009, p. 37-56.

SERELLE, M. Profissão repórter revisitado: as dimensões do afeto. In: SOARES, R. L.; GOMES, M. R. (Org.). Profissão Repórter em diálogo. São Paulo: Alameda, 2012, p. 177-187.

SODRÉ, M. A narração do fato: notas para uma teoria do acontecimento. Petrópolis: Vozes, 2009.

SONTAG, S. Diante da dor dos outros. São Paulo: Cia. das Letras, 2003.

TAIT, S. Bearing witness, journalism and moral responsibility. Media, Culture \& Society, v. 33, n. 8, p. 1220-1235, 2011. 
VAZ, P.; RONY, G. Políticas do sofrimento e as narrativas midiáticas de catástrofes naturais. FAMECOS, v. 18, p. 218-234, 2011.

ZAGHETTO, S. Trabalho Ainda Ameaça Infância. Diário do Pará, Belém, 30 mar. 2008, p. A10.

ZELIZER, B. On "having been there": "eyewitnessing" as a journalistic key word. Critical Studies in Media Communication, v. 24, n. 5, p. 408428, 2007.

Danila Cal is PhD in Social Communication by Federal University of Minas Gerais (UFMG). Associate Professor of the Master Program in Communication, Language and Culture of Amazon University (Unama). She is the coordinator of the research group "Communication, Politics and Subalternity" (Unama) and researcher of the "Media and Public Sphere" research group (UFMG). E-mail: danilagentilcal@gmail.com

Leandro Lage is $\mathrm{PhD}$ candidate in Social Communication at Federal University of Minas Gerais (UFMG). Researcher of the Tramas Comunicacionais Research Group (UFMG). Professor of Communication Studies at the Amazon University (Unama). E-mail: leandrorlage@gmail.com 